The complete results of the researches outlined above, with results obtained in vitro in the presence of blood and serum, and together with observations on the bacteriasthenicizing activity of the blood and serum of patients undergoing sulphonamide therapy, will be shortly published.

Ward, Blenkinsop and Co., Ltd.

M. Mandelbaum.

Research Laboratories,

London and Liverpool

(formerly Director, Bacteriological and

Serological Institute.

Hospital Munchen-Schwabing, Munich). Jan. 28.

\section{Vitamin Content of Salmon}

THE tables of the vitamin content of foods of Fixsen and Roscoe ${ }^{1}$ are in constant use in assessing the vitamin value of diets. Our attention, however, has recently been directed particularly to salmon. The vitamin A concentration of body oil and flesh oil is there given as 4,400-52,500 and 0-20,480 international units per 100 gm., while the vitamin D concentration of flesh oil is listed as 9,500 international units per $100 \mathrm{gm}$., and the vitamin D content of salmon flesh at 200-800. The ascorbic acid content given is $89 \cdot 9-215 \cdot 6 \mathrm{mgm}$. per $100 \mathrm{gm}$. of flesh. These vitamin $\mathrm{C}$ figures are higher than any reported for oranges and lemons and equal those given for varieties of blackcurrant, noted for their antiscorbutic properties. Taken together with a calorific content thrice that of orange juice, these values suggested that salmon might be regarded as deserving of precedence over the citrus fruits for import space.

Confirmation of these figures was desirable. Since most of the salmon eaten in Great Britain is tinned, twelve different brands were purchased in the open market, together with a chilled salmon weighing about $24 \mathrm{lb}$. This was kept in a cold store until a few minutes before the analyses were made. The accompanying table shows the results of the analyses on these.

\begin{tabular}{|c|c|c|c|}
\hline Sample. & $\begin{array}{l}\text { Vitamin } \mathbf{A} \\
\text { (blue value). }\end{array}$ & $\begin{array}{r}\text { Vitamin B } \\
(\mathrm{I} . \mathrm{U} . \mathrm{per} \\
100 \mathrm{gm} .) .\end{array}$ & $\begin{array}{l}\text { Vitamin C } \\
\text { (mgm. per } \\
100 \mathrm{gm} . \text { ). }\end{array}$ \\
\hline 1. Alaskan & nil & 10 & nil \\
\hline $\begin{array}{ll}2 . & , \\
3 . & ,\end{array}$ & ", & $\begin{array}{l}10 \\
10\end{array}$ &, \\
\hline 4. English (probably) & ", & 15 & ", \\
\hline $\begin{array}{ll}5 . & , \\
6 . & ,\end{array}$ & ," & $\begin{array}{l}11 \\
8\end{array}$ & $"$ \\
\hline 7. Sco"tish (trob" " & ", & 11 & ", \\
\hline 9. "scottisn (probably) & ", & $\begin{array}{l}8 \\
8\end{array}$ & $\because$ \\
\hline 10. 'Foreign' ", & ", & $\begin{array}{r}10 \\
8\end{array}$ & ", \\
\hline 12. Japantese & ", & & ", \\
\hline a. Middle cut & nil & 76 & 9 \\
\hline b. Tail cut & nil & 86 & 9 \\
\hline d. Roe (hard) & 30 & 190 & 21 \\
\hline e. Intestine & 33 & 28 & 10 \\
\hline $\begin{array}{l}\text { f. Pancreas } \\
\text { g. Heart }\end{array}$ & 154 & 34 & $\begin{array}{l}6 \\
8\end{array}$ \\
\hline h. Gills & nil & nil & 4 \\
\hline
\end{tabular}

Vitamin A was'determined by hydrolysis of the fish sample in methyl-alcoholic potash and measurement of the antimony trichloride 'blue value' calculated to a 20 per cent solution of the original sample on the non-saponifiable residue. No carotene was detected. Vitamin $B_{1}$ was determined by the thiochrome method; vitamin $\mathrm{C}$ by titration with $2 \cdot 6$ dichlorophenol indophenol.
A representative sample of the whole material from one of the tins listed above was assayed biologically on chicks by the B.S.I. standard radiographic technique for vitamin $D_{3}$. It gave a figure of 600 units per $100 \mathrm{gm}$. of flesh with fiducial limits at $\mathbf{P}=0.95$ of $83-119$ per cent. This agrees with Fixsen and Roscoe's figure quoted.

From this work, it appears that, although fresh salmon may contain the large vitamin stores attributed to it, the material that reaches the table of the British housewife is far from being as rich in vitamins $\mathrm{A}$ and $\mathrm{C}$ as hitherto published figures would suggest.

Research Laboratories,

Vitamins, Ltd.,

London, W.6. Jan. 16.

${ }^{1}$ Nutrition Abst. and Rev., 7, 823 (1937-38); 9, 795 (1939-40).

\section{Weather, Wild Birds and Home-grown Food}

THE effects of the severity of the winter of many years back on wild birds have been described by various writers from 1408 onwards, but coming to more recent times we have the comprehensive account given by James Hardy and others ${ }^{1}$ for the winter of $1879-80$, that of $\mathrm{A}$. W. Preston ${ }^{2}$ for $1890-91$ and other references to the winter of 1894-95. Still more recently we have the excellent account by Jourdain and Witherby ${ }^{3}$ of the disastrous effects of the winter of 1894-95, and finally the very full and valuable account of the effects of the particularly severe winter of 1939-40 given by Ticehurst and Witherby ${ }^{4}$.

It is unnecessary here to detail the enormous reductions that have taken place in our wild bird fauna. They are very serious and the repercussions will be of a far-reaching nature.

Those interested in economic biology know what an enormous amount of home-grown food was destroyed by injurious insects and rodents in 1917 and 1918, and there seems no reason for supposing that any but similar conditions will prevail in 1941 and 1942, unless some wise and well thought out action is taken quickly.

Writing in $1918^{5}$ I have pointed out that "All who take an interest in the ways and habits of wild animal life must have been struck by this curious coincidence-namely, during the spring and summer of 1917, very many of our commoner species of wild birds were apparently rare, and injurious insects and rodents were particularly abundant; during 1918 the same phenomenon was still more noticeable, the insects being exceedingly abundant, in many districts sufficiently numerous to constitute a plague. As a result of this dislocation of the so-called balance of nature an enormous amount of home-grown food has been lost".

To-day it is not enough for the farmer and fruit grower to grow abundant crops if such cannot be harvested clean and free from disease. Every year vast quantities of such food are destroyed by injurious insects and rodents, and this year and next, owing to the great reduction in our wild bird population, that amount will increase to an enormous extent, and although we are increasing the acreage cultivated, the sum total, in very many cases, instead of being more, will be less.

In view of the seriousness of the situation, I suggest that the destruction or taking of any wild birds or 